\title{
A CLINICAL STUDY OF SERUM MAGNESIUM CONCENTRATIONS DURING ANAESTHESIA AND CARDIOPULMONARY BYPASS
}

\author{
R.K. CALVERLeY, M.D., F.R.C.P.(c) ${ }^{*}$, L.C. JeNKins, B.A., M.D., C.M., F.R.C.P.(c) †, \\ AND JoHN GrIFFITHS, B.SC., M.B., B.CH. $\neq$ with the technical assistance of \\ K. SARUdNY
}

IN THE PAST DECADE several investigators have studied the physiological activities and pharmacological applications of magnesium. This interest has been facilitated by the development of atomic absorption spectrophotometry, which permits the accurate determination of magnesium concentrations in serum, plasma and urine. ${ }^{1}$

Two experimental studies have shown unexpected alterations in serum magnesium concentrations in the rat and the pig following the administration of morphine and halothane., ${ }^{2,3}$ Since comparable clinical data could not be found, we have investigated serum magnesium levels during general and conduction anaesthesia. If significant alterations could be observed consistently, these changes might reflect redistribution of magnesium from tissue stores under the influence of anaesthetic agents.

As an introduction to these investigations the role of magnesium in homeostasis will be reviewed and a few pertinent pharmacological observations will be presented.

\section{Body Content and Metabolism ${ }^{4}$}

Magnesium is the fourth most abundant cation in the body. Calcium, sodium and potassium are the only cations present in greater amount. The magnesium content of an adult is approximately $30 \mathrm{gm}$. Over 50 per cent of total body magnesium is within bone. Thirty-five per cent of magnesium is intracellular. The concentration within the cell is exceeded only by potassium. The highest intracellular concentrations of magnesium are observed in striated muscle and liver.

One third of serum magnesium is protein bound. The remainder is diffusible. In our laboratory normal serum concentrations range from 1.8 to $2.9 \mathrm{mg} \%$. In some publications serum magnesium concentrations are expressed as milliequivalents/liter, but milligrams per cent is more appropriate since only two-thirds of

Presented at the Canadian Anaesthetists' Society 1972 Annual Meeting in Halifax, Nova Scotia.

${ }^{*}$ Department of Anaesthesia and the Clinical Chemistry Laboratory, Vancouver General Hospital, Vancouver, B.C.

†Director, Department of Anaesthesia, Vancouver General Hospital. Professor and Head, Department of Anaesthesia, University of British Columbia.

fDr. John Griffiths is now Chairman, Department of Clinical Biochemistry, University Hospital, University of Western Ontario, London 11, Ontario. 
the total in the serum is free ions. At present it is only possible to measure total serum magnesium concentrations accurately.

The homeostatic mechanisms maintaining serum magnesium concentrations within the narrow range of \pm 5 micrograms per milliliter of serum are not completely understood. Multiple factors influence the absorption, including growth hormone, parathyroid hormone and Vitamin D. Reabsorption of magnesium from urine is enhanced by parathyroid hormone, but is reduced by glucagon, growth hormone, aldosterone, cortisone and calcitonin.

The magnesium concentration in cerebrospinal fluid is higher than in serum. The reason for this is unknown.

Approximately one-third of ingested magnesium is absorbed. Excretion occurs in the urine and stool. Renal tubular reabsorption is important. There is a daily urinary loss of about $100 \mathrm{mg}$, or about 3 per cent of the magnesium presented in the glomerular filtrate.

\section{Physiological Role of Magnesium}

Magnesium is an activator or catalyst of a great number of enzyme systems which critically influence organ function and cellular metabolism. While many of the following observations are based upon "in vitro" analysis, it is interesting to note that high magnesium concentrations are consistently found in tissues with high metabolic activity.

\section{Intracellular Functions of Magnesium}

Some intracellular functions of magnesium include:

(1) Protein Synthesis: Magnesium is required for most of the reactions leading to the synthesis of protein, from the activation of the individual amino acid components to the stablization of the organization of DNA, RNA and ribosomes. ${ }^{5}$

(2) Activator of Enzyme Systems: ${ }^{6}$ Magnesium is required in phosphate - transfer reactions and in the cytochrome system in oxidative phosphorylation.

(3) Relationship with other Electrolytes

Sodium and potassium: Transmembranous potassium and sodium transport are regulated by magnesium activated, ATP-driven, cellular transport mechanisms. ${ }^{7}$

Calcium: In a relationship similar to the intracellular-extracellular ratios of sodium and potassium, magnesium is present in higher concentrations within the cell, while calcium is concentrated extracellularly. ${ }^{8}$

Magnesium influences serum calcium concentrations. Hypomagnesaemia impedes the parathyroid hormone-mediated release of calcium from bone. ${ }^{9}$ In some patients low urinary magnesium excretion leads to the formation of calcium-containing renal calculi. ${ }^{10}$

\section{Extracellular Actions}

(1) Cardiovascular System

(i) Cardiac Effect: As well as having a fundamental role in the liberation of 
energy by cardiac muscle cells, disturbances of magnesium concentration affect myocardial conductivity. ${ }^{11}$

(ii) Vascular Effect: Hypermagnesaemia causes vasodilatation. ${ }^{12}$ This response of vascular smooth muscle is caused by enzymatic processes or alterations of membrane potential.

(2) Neuromuscular Junction

Neuromuscular transmission is enhanced by hypomagnesaemia. In contrast excessive concentrations of magnesium depress neuromuscular transmission at pre-synaptic and post-synaptic sites. In the presence of high serum levels of magnesium the blockade at the neuromuscular junction is the result of (a) a decrease in the amount of acetylcholine liberated from the motor nerve terminal, $(b)$ diminution in the depolarizing action of acetylcholine at the end-plate, and $(c)$ depression of the excitability of the muscle fiber membrane. ${ }^{13}$

\section{Disease States Associated with Abnormal Magnesium Concentrations}

\section{(1) Magnesium Deficiency ${ }^{14}$}

Magnesium deficiency occurs in the presence of deranged hormonal control, inadequate intake and absorption, or excessive renal loss. Symptomatic hypo magnesaemia may be caused by gastrointestinal disorders including malabsorption syndromes, fistulae, prolonged diarrhoea, hepatic cirrhosis, and by endoctrinopathies, particularly hyperparathyroidism and hypoparathyroidism. Other causes include some renal diseases, diabetic acidosis, alcoholism and diuretic therapy. A complete discussion of hypomagnesaemia is provided in an excellent review by Wacker and Parisi. ${ }^{15}$

While anaesthetists may be involved in the management of patients with any of these conditions, they should be particularly alert for the presence of hypomagnesaemia in the debilitated patient with impaired nutrition. ${ }^{16,17}$ When dietary intake has been severely restricted for more than one month, intravenous solutions may compound this problem. Wound healing, which is a post-operative anabolic response, is also magnesium dependent. Relatively acute magnesium deficiency has been observed in severely burned patients. ${ }^{18}$ Following extensive trauma, excessive amounts of intracellular magnesium may be released and excreted as renal conserving mechanisms are overcome.

Signs and Symptoms: Magnesium deficiency in man leads to central nervous system and neuromuscular dysfunction manifested by hyperexcitability and behavioural disturbances. Tetany, seizures, tremors, ataxia, vertigo and muscle weakness may be noted. Depression, confusion and psychotic behaviour are sometimes seen. Hyper-reflexia and a Babinski reaction may be detected. Parenteral calcium therapy will not stop tetany due to hypomagnesaemia. These disturbances are reversed by parenteral magnesium. ${ }^{19}$ Electrocardiographic changes have been described which include a shortened PR interval, ST depression and T-wave inversion. ${ }^{20}$ Magnesium depleted rats and mice develop cardiac and skeletal myopathy. ${ }^{21}$ 
Investigations: Serum analysis may or may not show reduced serum levels. Normal values may be maintained by complex hormonal controls despite severe depletion, for reasons which are not completely understood. Decreased excretion of magnesium may be found by analyzing a 24-hour collection of urine. The concentrations of magnesium in red cells and biopsied muscle are reduced in states of chronic deficiency. ${ }^{22}$

Treatment: Patients on long-term intravenous therapy should receive 10 $\mathrm{mEq}$ of magnesium daily to prevent magnesium deficiency.

Patients with tetany due to hypomagnesaemia may receive magnesium intravenously at a rate which should not exceed $150 \mathrm{mg}$ per minute. Tetany often resolves when less than one gram has been given. Further parenteral therapy can be given intramuscularly. ${ }^{23}$

(2) Magnesium Excess

Symptomatic hypermagnesaemia occurs in patients with renal failure. ${ }^{24} \mathrm{Ex}$ cessive oral intake and absorption may occur in Epsom salts poisoning. ${ }^{25}$ Aggressive parenteral therapy in the treatment of eclampsia may precipitate magnesium excess. Since magnesium crosses the placenta, infants born of eclamptic mothers have been flaccid as a result of acute hypermagnesaemia. ${ }^{26}$ Hypermagnesaemia may be diagnosed by elevated serum magnesium concentrations. Experimental investigators have shown a progression of signs which could be related to serum concentrations of magnesium in animals. At a serum concentration of 5 to $10 \mathrm{mg} \%$, electrocardiographic changes included a prolongation of the PR interval and widening of the QRS complex, increased amplitude of the $\mathrm{T}$ waves and a prolonged QT interval. Deep tendon reflexes are lost when the serum concentration approaches $10 \mathrm{mg} \%$ and respiratory paralysis occurs near $15 \mathrm{mg} \%$. Cardiac arrest in diastole occurs at concentrations in excess of $25 \mathrm{mg} \% .^{27}$

The traditional treatment of hypermagnesaemia is the intravenous administration of calcium which antagonizes the extracellular actions of magnesium at the neuromuscular junction. Ventilatory support may be required as part of supportive therapy. Gastric aspiration is of value after oral poisoning. Haemodialysis may be required in the treatment of massive intoxications. ${ }^{28}$

\section{Pharmacological Considerations}

The pharmacological considerations of magnesium can be conveniently divided into two parts. Exogenous magnesium can be employed for specific therapeutic effects, while endogenous magnesium influences the action of other drugs.

\section{Therapeutic Uses of Magnesium ${ }^{29}$}

(1) Antacids and Purgatives

Magnesium is a constituent of many antacids and purgatives. While the absorption of magnesium through the intestinal mucosa is limited by hormonal action, 10 per cent of large amounts of ingested magnesium can be absorbed. Antacids can cause symptomatic hypermagnesaemia in patients with poor renal function. 
(2) Magnesium Deficiency

Parenteral replacement with magnesium sulfate or magnesium chloride is the specific therapy for magnesium deficiency. If tetany is present, the intravenous route should be used initially.

(3) Eclampsia

Magnesium is an effective agent in the control of convulsions and cerebral irritability in eclamptic patients.

(4) Experimental Uses

(i) Antidysrhythmic Activity

Magnesium has been employed with success to reverse persistent ventricular fibrillation after hypothermic cardiopulmonary bypass..$^{30,31}$

(ii) Magnesium as an Anaesthetic Agent

Fifty years ago intravenous magnesium sulfate was employed experimentally as a general anaesthetic. ${ }^{32}$ Somjen et $a l^{33}$ have challenged this effect by showing that even when hypermagnesaemia caused total muscle paralysis, the subjects did not lose consciousness or pain perception.

Kato et al. ${ }^{34}$ presented a study at the Canadian Anaesthetists' Society meeting in 1968 which examined micropipette applications of magnesium to discrete centres in the cerebral cortex and spinal cord of cats. In contrast to the predominant pre-synaptic effect at the neuromuscular junction, the major effect observed in the central nervous system was a post-synaptic depression of excitability.

(iii) Succinyldicholine Hyperkalaemia

Magnesium sulphate has been used experimentally to diminish succinyldicholine-induced hyperkalaemia and muscle fasciculations. ${ }^{35}$

\section{Interactions Between Magnesium and other Therapeutic Agents}

There are several important interactions between endogenous magnesium and therapeutic agents employed by anaesthetists. These drugs include diuretics, digitalis and muscle relaxants.

\section{Diuretics}

Chlorothiazides, thiomerin and other diuretics cause an increase in urinary magnesium loss. ${ }^{36}$ The hypotensive effect of diuretics may be the result of a relative magnesium depletion affecting vascular smooth muscle tone. ${ }^{37}$

\section{Digitalis $^{38,39}$}

Intravenous infusion of magnesium promptly terminates toxic dysrhythmias due to digitalis intoxication associated with low serum magnesium levels. ${ }^{40}$ Magnesium promotes the intracellular movement of potassium, thereby antagonizing the effect of digitalis.

\section{Muscle Relaxants}

Ghoneim and Long ${ }^{11}$ have demonstrated that magnesium augments the neuromuscular blockade produced by d-tubocurare, decamethonium and succinyldicho- 
line. Their study was prompted by two cases in which patients with preeclampsia received magnesium sulfate and were subsequently given curare during anaesthesia. One patient developed apparent "recurarization" after a single post-operative dose of magnesium sulfate. The second patient showed persisting paralysis unresponsive to neostigmine after large doses of magnesium. These observations stimulated a laboratory study with rats. Magnesium increased the neuromuscular blockade of curare, decamethonium and succinyldicholine. The least degree of augmentations was noted with succinyldicholine, possibly because magnesium also augments the action of pseudocholinesterase.

\section{Morphine}

Large doses of morphine ( 2 to $16 \mathrm{mg} / \mathrm{kg}$ ) caused an elevation of serum magnesium in rats. ${ }^{42}$

\section{Halothane}

An investigation of malignant hyperpyrexia precipitated in Landrace pigs by halothane anaesthesia has shown a marked and acute hypermagnesaemia. ${ }^{43}$ Comparable data in man have not been presented.

These observations stimulated interest in the diverse actions of magnesium in homeostasis. We set out to learn if the techniques and agents employed in general anaesthesia and conduction anaesthesia might cause any derangement in serum magnesium concentrations.

\section{METHOD}

The subjects of this study were 74 adult patients undergoing surgical operations at the Vancouver General Hospital.

Serial venous specimens were obtained from groups of patients undergoing spinal anaesthesia, general anaesthesia and cardiopulmonary bypass. Samples were drawn from 59 patients before, during, and after anaesthesia. Additional samples were taken from these patients and from the remaining 15 patients both before and after the administration of specific pharmacological agents.

Urine was collected from patients undergoing cardiopulmonary bypass and neurosurgical operations.

Technique of Sampling: Ten milliliters of venous blood were withdrawn using a \#20 disposable needle and a plastic syringe. Excessive suction was avoided to eliminate haemolysis. Venous tourniquet time was minimized to avoid changes in serum magnesium caused by altered $\mathrm{pH}$ or increased red cell volume. The serum was separated by centrifugation after clot stabilization. The specimens were then delivered to the Chemistry Laboratory.

Magnesium analysis was performed by atomic absorption spectrophotometry. A single Instrumentation Laboratories Model 153 spectrophotometer was employed by two technologists only. Quality control of known concentration was run parallel with each series of determinations. Each specimen was analyzed with two recoveries (standards by addition).

\footnotetext{
"Instrumentation Laboratories Inc., 113 Hartwell Avenue, Lexington, Mass. 02173.
} 


\section{PREOPERATIVE SERUM MAGNESIUM}

(59 Patients)

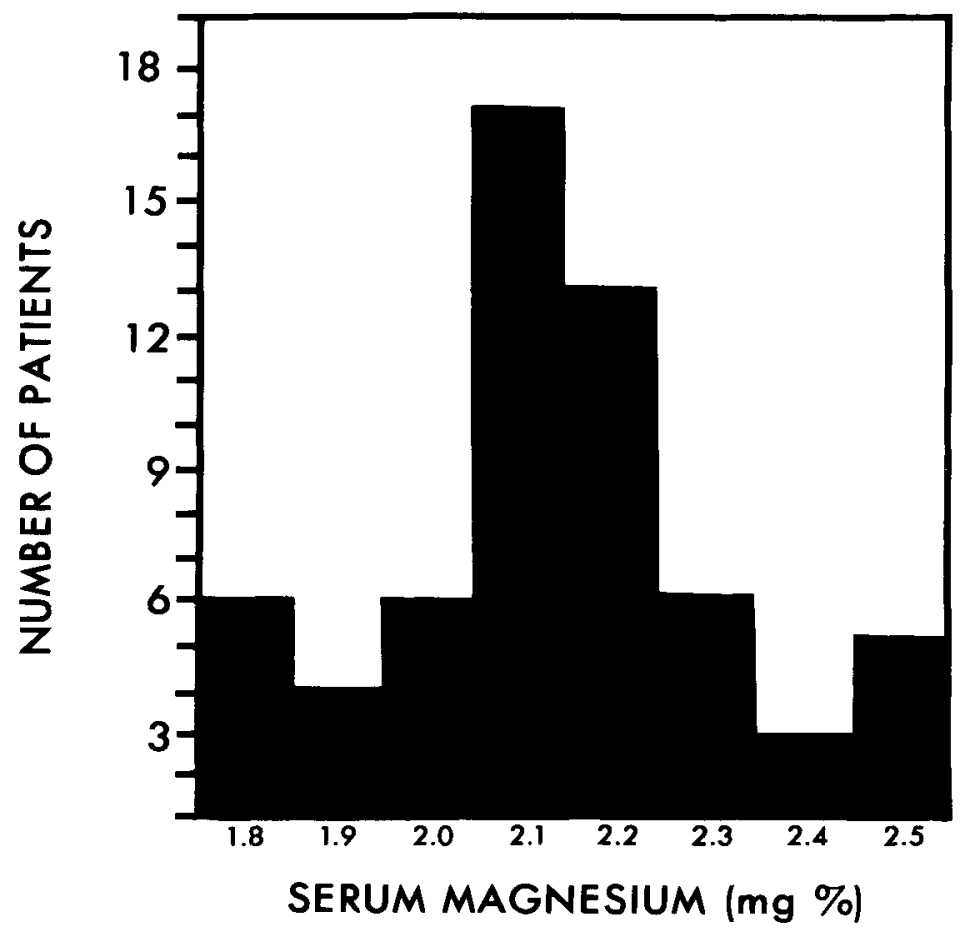

Figure 1. Preoperative serum magnesium.

Total serum magnesium is reported to one-tenth of a milligram per one hundred milliliters of serum ( $0.1 \mathrm{mg} \%$ ), but duplicate determinations on the same sample may vary by $\pm 0.1 \mathrm{mg} \%$. When two serial specimens are compared, the potential laboratory difference of $\pm 0.1 \mathrm{mg} \%$ woull be doubled and, therefore, serial differences must exceed $\pm 0.2 \mathrm{mg} \%$ before factors related to the analysis of the specimens can be excluded.

\section{Results AND Discussion}

\section{Pre-Operative Results}

Pre-operative serum magnesium levels for 59 patients are reported in Figure 1. All of these determinations fall within the normal range of 1.8 to $2.9 \mathrm{mg} \%$.

\section{Spinal Anaesthesia}

We surveyed 13 consecutive patients undergoing tetracaine spinal anaesthesia for transurethral resection of the prostate. The first specimen was taken five minutes before the intrathecal injection; the second, during resection between $\mathbf{4 0}$ and 60 minutes after the block had been established. The last specimen was drawn one-half hour after surgery. 

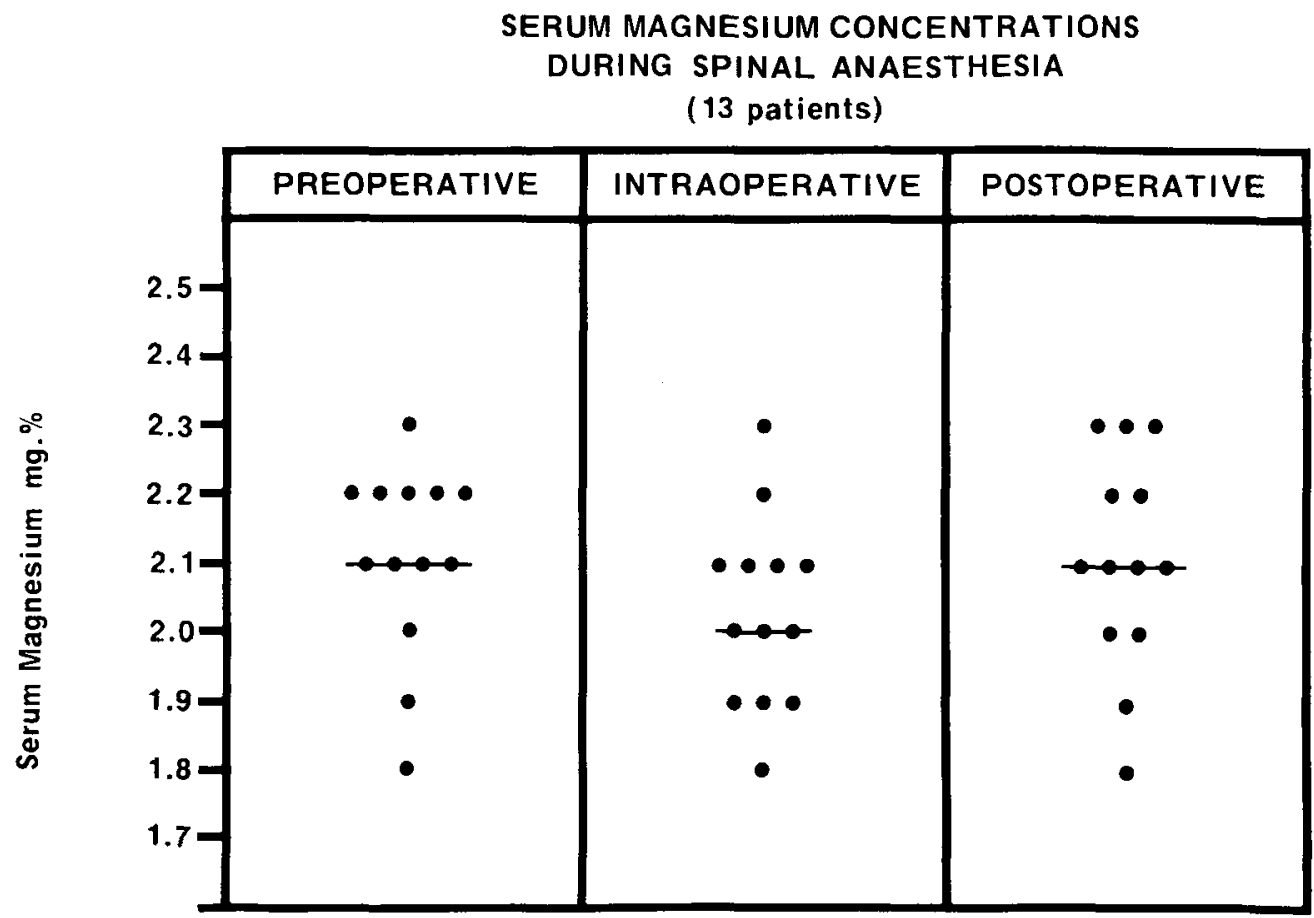

Figure 2. Serum magnesium concentrations during spinal anaesthesia.

The results of these analyses are displayed graphically in Figure 2. All sample values in each part of the survey are within the normal range. The mean values in each period are indicated by a horizontal bar. The standard deviation has been $\pm 0.1 \mathrm{mg} \%$ for each of the three periods. There is, therefore, no significant difference by the $t$-test between the means of any of the three groups of values.

Since it is possible that significant changes may have occurred in individual patients, we have analyzed the individual changes for each patient between each sample collected. This information is presented in Figure 3. Six patients ( 46 per cent) maintained identical values throughout the three sampling periods. Seven (54 per cent) showed an insignificant fall when the intra-operative specimen was drawn. In the interval between the intra-operative and post-operative samples, only two of thirteen patients showed a change beyond the range of the accuracy of the test. These elevations returned the post-operative serum magnesium value to within $\pm 0.2 \mathrm{mg} \%$ of the patients' pre-operative value.

It is our impression that no significant changes in serum magnesium concentration occurred in these thirteen patients during tetracaine spinal anaesthesia for prostatic resection.

\section{General Anaesthesia (excluding cardiopulmonary bypass)}

Thirty-five patients were assessed at intervals during general anaesthesia. We drew specimens before premedication, after 30 to 40 minutes of anaesthesia with a variety of inhalational agents and again 15 to 25 minutes after the end of anaes- 
CHANGES IN SERUM MAGNESIUM CONCENTRATIONS DURING SPINAL ANAESTHESIA

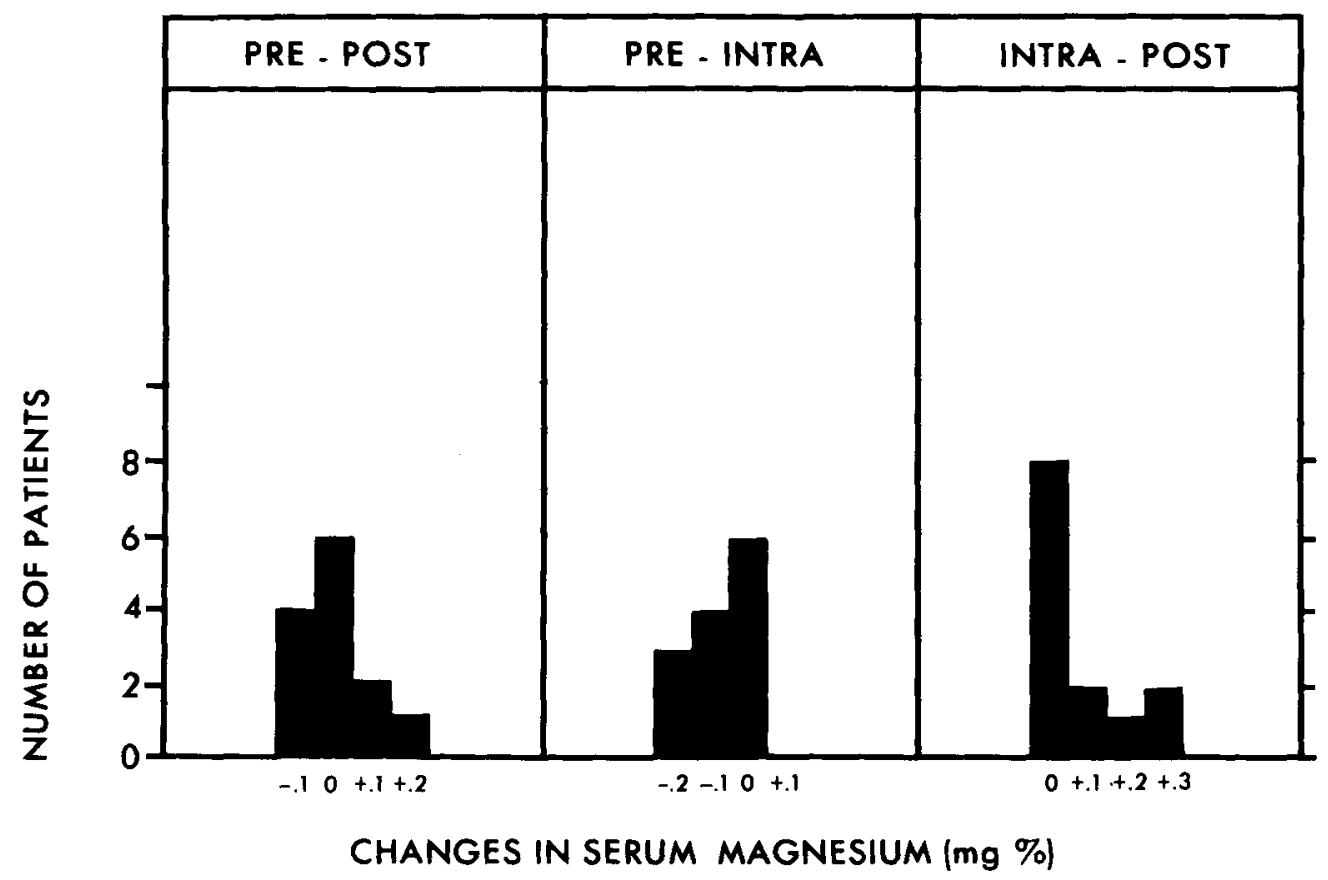

FIguRE 3. Changes in serum magnesium concentrations during spinal anaesthesia.

thesia. The patients had a variety of general surgical, orthopaedic and neurosurgical operations lasting from 40 minutes to 4 hours, 20 minutes. Blood loss varied from a few milliliters to 2,200 ccs during porto-caval bypass.

The pre-operative, intra-operative and post-operative values are displayed in Figure 4. Mean values are indicated by a horizontal bar and are identical throughout the study. The standard deviation of each series of thirty-five samples has remained at $\pm 0.2 \mathrm{mg} \%$. Since there is no difference in means or standard deviations, there is no significant difference among the three sets of determinations.

All of the values remain within the normal ranges except for two values of 1.7 $\mathrm{mg} \%$ which were observed in a patient undergoing porto-caval bypass whose preoperative serum magnesium was $1.9 \mathrm{mg}$.

A comparative analysis of individual changes in sermu magnesium is presented in Figure 5. The mean change remains at zero change in all three periods and the standard deviations remain within the range of the test. Changes which narrowly exceed the ranges of the test were observed in only 8 of the 105 comparisons.

\section{Specific Anaesthetic Agents}

We assessed changes in serum magnesium concentration before and following the administration of specific agents. These have included pre-medicants, induc- 
SERUM MAGNESIUM CONCENTRATIONS

DURING GENERAL ANAESTHESIA

(35 patients)

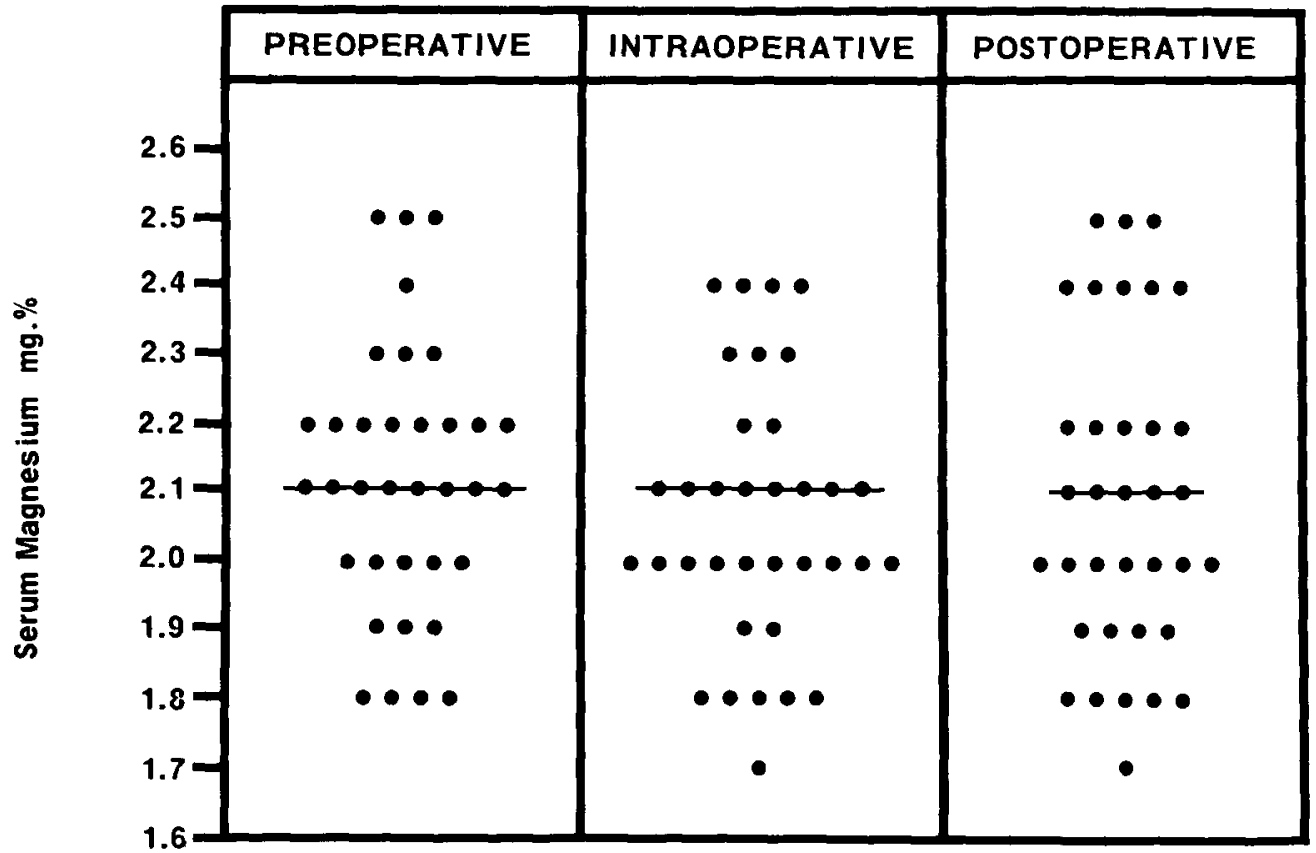

Frgure 4. Serum magnesium concentrations during general anaesthesia.

tion agents, inhalation and intravenous anaesthetic agents and muscle relaxants. Ketamine and pancuronium were not available during the study period.

In each case, values are reported only when specimens were taken less than five minutes before and less than 5 to 25 minutes after the administration of a drug. The shorter interval of five minutes was selected for thiopentone, succinyldicholine and decamethonium. The longer interval was employed for drugs with more sustained action. The results are shown in Table I.

The mean change for each drug assessed is within the range of laboratory variation. The standard deviation corrected for small sample size for each drug or drug combination is also not significant. We have not observed any changes which would suggest that anaesthetic agents cause a significant change in serum magnesium concentration during clinical anaesthesia.

\section{Other Drugs Commonly Employed by Anaesthetists}

The series was extended to include a small sampling of patients receiving nonanaesthetic drugs employed during clinical anaesthesia (Table II). The mean change and standard deviations are all within the range of laboratory variation.

\section{Diuretic Agents}

Serum magnesium concentrations remained stable following the intra-operative administration of mannitol ( Table II). We assessed the effect of mannitol on mag- 


\section{CHANGE IN SERUM MAGNESIUM CONCENTRATIONS DURING GENERAL ANAESTHESIA}

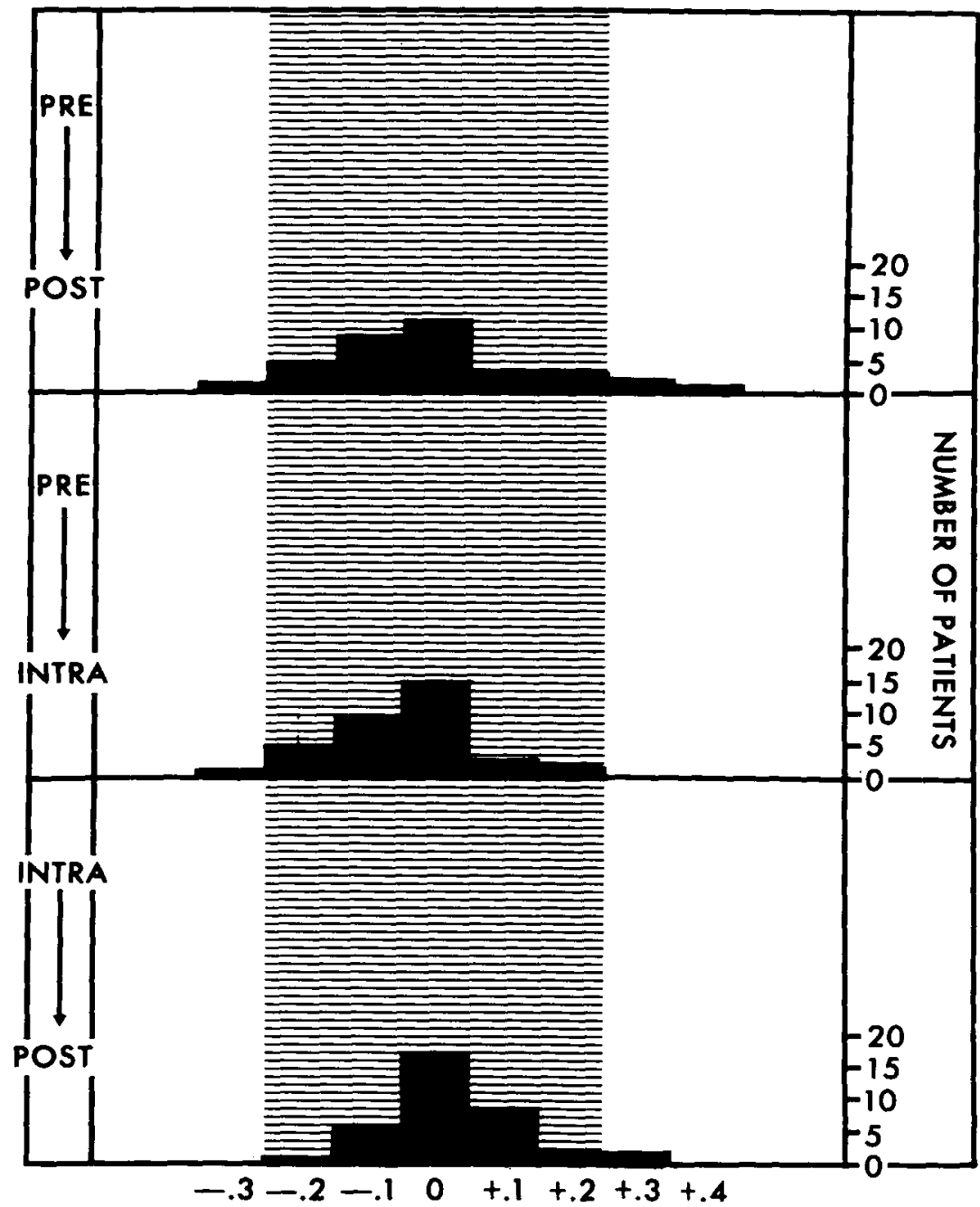

Figure 5. Change in serum magnesium concentrations during general anaesthesia.

nesium excretion during prolonged neurosurgical operations (Figure 6). Two other neurosurgical patients served as controls.

An osmotic diuresis does cause an increased excretion of magnesium, but some degree of tubular conservation of magnesium is maintained, as magnesium excretion does not rise in direct proportion to the increase in urine formation.

One other patient received 80 milligrams of furosemide intravenously immediately after. surgery. Over the next four hours 1,900 milliliters of urine were passed and 100 milligrams of magnesium were excreted without any change in the serum concentration. Subsequently the patient demonstrated marked conservation of magnesium as he voided only 15 milligrams of magnesium in the next 12 hours. 
TABLE I

The Effect of Anaesthetic Agents on Serum Magnesium

\begin{tabular}{|c|c|c|c|c|c|c|c|c|c|}
\hline \multirow[b]{2}{*}{ Anaesthetic Agent } & \multirow{2}{*}{$\begin{array}{l}\text { Total } \\
\text { No. of } \\
\text { Patients }\end{array}$} & \multicolumn{8}{|c|}{ Change in Serum Magnesium in $\mathrm{mg} \%$} \\
\hline & & -0.4 & -0.3 & -0.2 & -0.1 & 0 & +0.1 & +0.2 & +0.3 \\
\hline $\begin{array}{l}\text { Premedication } \\
\text { Diazepam and Atropine } \\
\text { Meperidine and Atropine } \\
\text { Pantopon and Atropine } \\
\text { Hyoscine }\end{array}$ & $\begin{array}{l}7 \\
6 \\
2 \\
3\end{array}$ & & & $\begin{array}{l}3 \\
1 \\
2\end{array}$ & $\begin{array}{l}1 \\
2\end{array}$ & $\begin{array}{l}3 \\
2\end{array}$ & $\begin{array}{l}1 \\
1\end{array}$ & & \\
\hline $\begin{array}{l}\text { Induction Drugs } \\
\text { Thiopentone and } \\
\text { Succinyldicholine } \\
\text { Thiopentone \& } \mathrm{N}_{2} \mathrm{O} \\
\text { Diazepam and } \\
\text { Succinyldicholine } \\
\text { Methohexital } \\
\text { Innovar }\end{array}$ & $\begin{array}{l}8 \\
3 \\
4\end{array}$ & & $\begin{array}{l}2 \\
1\end{array}$ & $\begin{array}{l}2 \\
1\end{array}$ & $\begin{array}{l}4 \\
2 \\
2\end{array}$ & 2 & 1 & & \\
\hline $\begin{array}{l}\text { Inhalation Anaesthetics } \\
\text { Halothane \& } \mathrm{N}_{2} \mathrm{O} \\
\text { Methoxyflurane \& } \mathrm{N}_{2} \mathrm{O}\end{array}$ & $\begin{array}{l}19 \\
10\end{array}$ & & & 5 & $\begin{array}{l}9 \\
2\end{array}$ & $\begin{array}{l}4 \\
3\end{array}$ & $\begin{array}{l}1 \\
3\end{array}$ & 2 & \\
\hline $\begin{array}{l}\text { Intravenous Anaesthetics } \\
\text { Alphaprodine \& } \mathrm{N}_{2} \mathrm{O} \\
\text { Morphine \& } \mathrm{N}_{2} \mathrm{O}\end{array}$ & $\begin{array}{r}16 \\
8\end{array}$ & & & $\begin{array}{l}2 \\
3\end{array}$ & $\begin{array}{l}2 \\
3\end{array}$ & $\begin{array}{l}6 \\
2\end{array}$ & 4 & 2 & \\
\hline $\begin{array}{l}\text { Muscle Relaxants } \\
\text { d-tubocurare } \\
\text { Gallamine } \\
\text { Decamethonium } \\
\text { Succinyldicholine }\end{array}$ & $\begin{array}{r}19 \\
5 \\
3 \\
7\end{array}$ & 1 & & $\begin{array}{l}1 \\
1 \\
1 \\
1\end{array}$ & $\begin{array}{l}3 \\
3 \\
2\end{array}$ & 4 & $\begin{array}{l}3 \\
1 \\
2\end{array}$ & 3 & \\
\hline $\begin{array}{l}\text { Reversal of Muscle } \\
\text { Relaxants } \\
\quad \text { Atropine \& Scopolamine }\end{array}$ & 7 & & & & 1 & 3 & & 3 & \\
\hline
\end{tabular}

TABLE II

Non-Anaesthetic Drugs Employed by Anaesthetists

\begin{tabular}{|c|c|c|c|c|c|c|c|c|}
\hline & \multirow{2}{*}{$\begin{array}{c}\text { Total } \\
\text { No. of } \\
\text { Patients }\end{array}$} & \multicolumn{7}{|c|}{ Change in Serum Magnesium mg\% } \\
\hline & & -0.3 & -0.2 & -0.1 & 0 & +0.1 & +0.2 & +0.3 \\
\hline $\begin{array}{l}\text { Heparin } \\
\text { Decadron } \\
\text { Afronad } \\
\text { Lidocaine } \\
\quad \text { (Intravenous) }\end{array}$ & $\begin{array}{l}4 \\
4 \\
2 \\
3\end{array}$ & & 1 & 1 & $\begin{array}{l}2 \\
1 \\
2 \\
3\end{array}$ & & 1 & \\
\hline $\begin{array}{l}\text { Pitocin } \\
\text { Mannitol }\end{array}$ & $\begin{array}{l}9 \\
2\end{array}$ & & & $\begin{array}{l}5 \\
1\end{array}$ & 2 & $\begin{array}{l}2 \\
1\end{array}$ & & \\
\hline
\end{tabular}

\section{Orthopaedic Surgery}

During orthopaedic procedures there are two potential causes for abrupt elevations in serum magnesium. Bone grafting causes major skeletal trauma. If a tourniquet is employed, prolonged tissue ischaemia could be associated with efflux of magnesium from the intracellular compartment to the interstitial fluid. Comparative specimens were taken immediately before and five minutes after the release of a thigh tourniquet. Two other neurosurgical patients served as controls. 


\section{INTRAOPERATIVE MAGNESIUM EXCRETION AFTER MANNITOL}

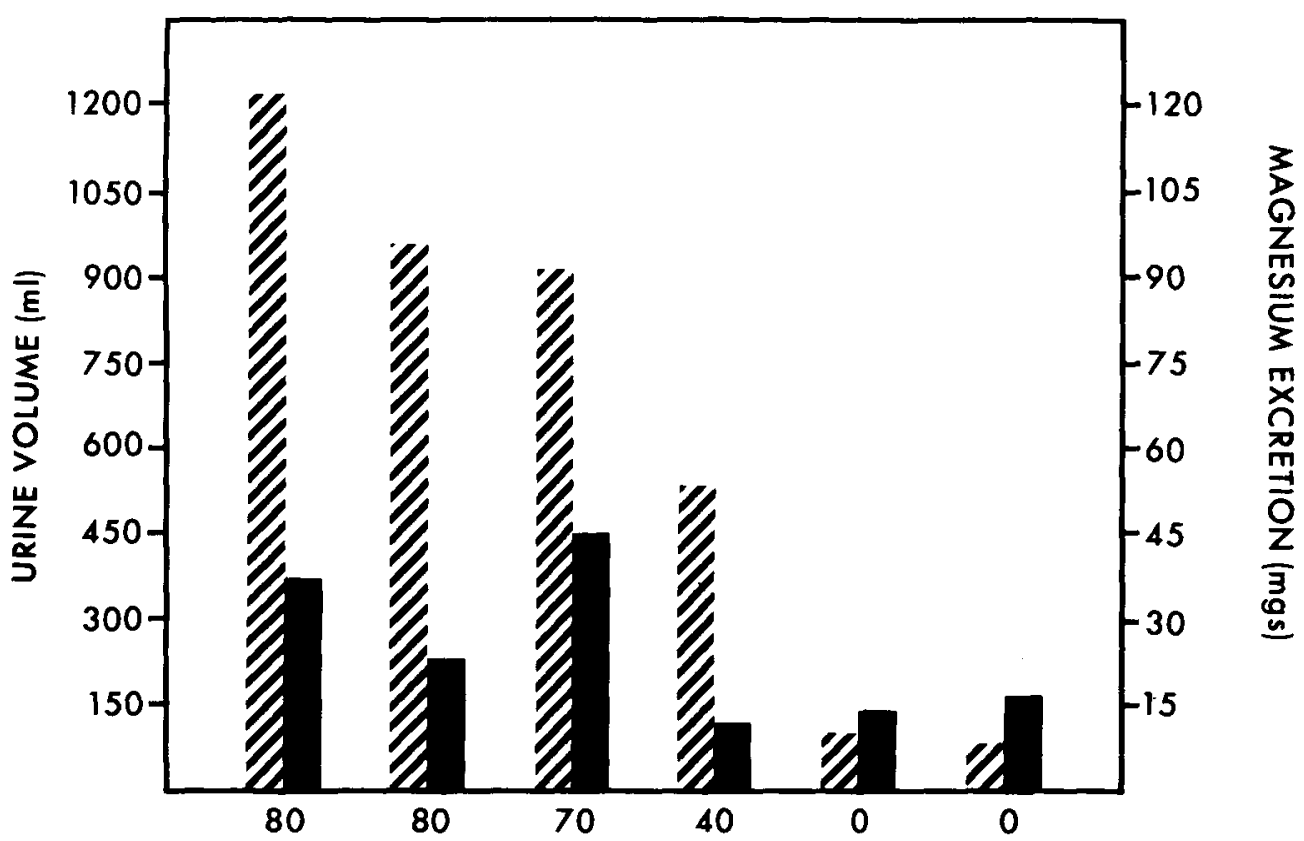

GRAMS OF MANNITOL

Figure 6. Intraoperative magnesium excretion after mannitol.

TABLE III

ORTHOPAEdic SURGERY

\begin{tabular}{|c|c|c|c|c|c|c|c|c|}
\hline & \multirow{2}{*}{$\begin{array}{c}\text { Total } \\
\text { No. of } \\
\text { Patients }\end{array}$} & \multicolumn{7}{|c|}{ Change in Serum Magnesium $\mathrm{mg} \%$} \\
\hline & & -0.3 & -0.2 & -0.1 & 0 & +0.1 & +0.2 & +0.3 \\
\hline \multicolumn{9}{|l|}{ Release of a } \\
\hline Tourniquet & 5 & & & 1 & 2 & 1 & 1 & \\
\hline Bone Graft & 9 & & & 3 & 3 & 2 & 1 & \\
\hline
\end{tabular}

We drew serial specimens from ten other patients immediately before and 10 to 15 minutes after trauma to bone. Both sets of results are presented in Table III. The mean change in each instance is zero change and the standard deviations are $\pm 0.1 \mathrm{mg} \%$. These orthopaedic operations have not caused significant changes in serum magnesium concentrations.

\section{Plasma Magnesium in Stored Blood}

When blood is stored in a blood bank, significant quantities of potassium migrate from the intracellular fluid of the erythrocyte to enter the plasma. There is a seven fold increase in plasma potassium during 21 days of storage. Magnesium is the second most abundant cation within the erythrocyte with a concentration of 65 milligrams per liter of intracellular fluid. Since the intracellular 


\begin{tabular}{lcc}
\hline & \multicolumn{2}{c}{ Pump Prime } \\
\cline { 2 - 3 } (1) Surgical Repair & & \\
(i) Mitral Valve & 2 & 2 \\
(ii) Aortic Valve & 1 & 1 \\
(iii) Aortic and Mitral Valves & 1 & 2 \\
(iv) Coronary Artery & 2 & 65 minutes \\
(2) Mean Pump Time & $71 \mathrm{minutes}$ & $2020 \mathrm{ml}$ \\
\hline
\end{tabular}

concentration is three times that of plasma, we wanted to learn if there was a comparable migration of magnesium from the intracellular to extracellular compartments during storage.

We analyzed plasma magnesium concentration in eleven units of stored blood. Samples were drawn with aseptic technique as the blood was prepared for administration. Three units were sampled one day after collection; three, 11 days after collection and three, 20 days after collection. The two remaining units of blood had been accidentally left unrefrigerated, but unopened, for 16 hours.

There was no evidence of a significant difference in the plasma magnesium concentration among any of the eleven units of blood. The plasma magnesium concentrations were all within the narrow range of 1.8 to $2.2 \mathrm{mg} \%$. There was no evidence of higher values with more prolonged storage or rewarming.

During collection the blood is diluted with Acid-Citrate-Dextrose solution. As it is impossible to measure the concentration of free magnesium ion in the clinical laboratory, we cannot determine the fraction of plasma magnesium which is present as a magnesium-citrate or magnesium-protein complex.

\section{Cardiopulmonary Bypass}

\section{(A) Serum Levels}

The authors of two clinical studies have shown significant falls in serum magnesium concentrations during cardiopulmonary bypass. Both groups of investigators primed the pump oxygenators with electrolyte solutions which did not contain magnesium. Dieter et al. (44) used a buffered lactated Ringer's solution and observed a mean decrease of $0.35 \mathrm{mEq} / \mathrm{L}(0.4 \mathrm{mg} \%)$ among 12 patients. Scheinman and his associates (45) reported a mean decrease of $0.49 \mathrm{mEq} / \mathrm{L}(0.6 \mathrm{mg})$ in 12 patients who had received No. 10 Travenol solution. Both investigators attributed the fall in serum magnesium to dilution of extracellular volume.

In contrast to the electrolyte priming solutions reported in these studies, the anaesthetists at the Vancouver General Hospital have preferred a haemodilution technique in which 1,500 milliliters of a buffered electrolyte solution was added to blood to prepare a priming solution for a disc or bubble oxygenator.

We performed serial serum magnesium determinations on 11 adult cardiac patients to determine if magnesium-containing electrolyte solutions might 


\section{SERUM MAGNESIUM}

(mg \%)

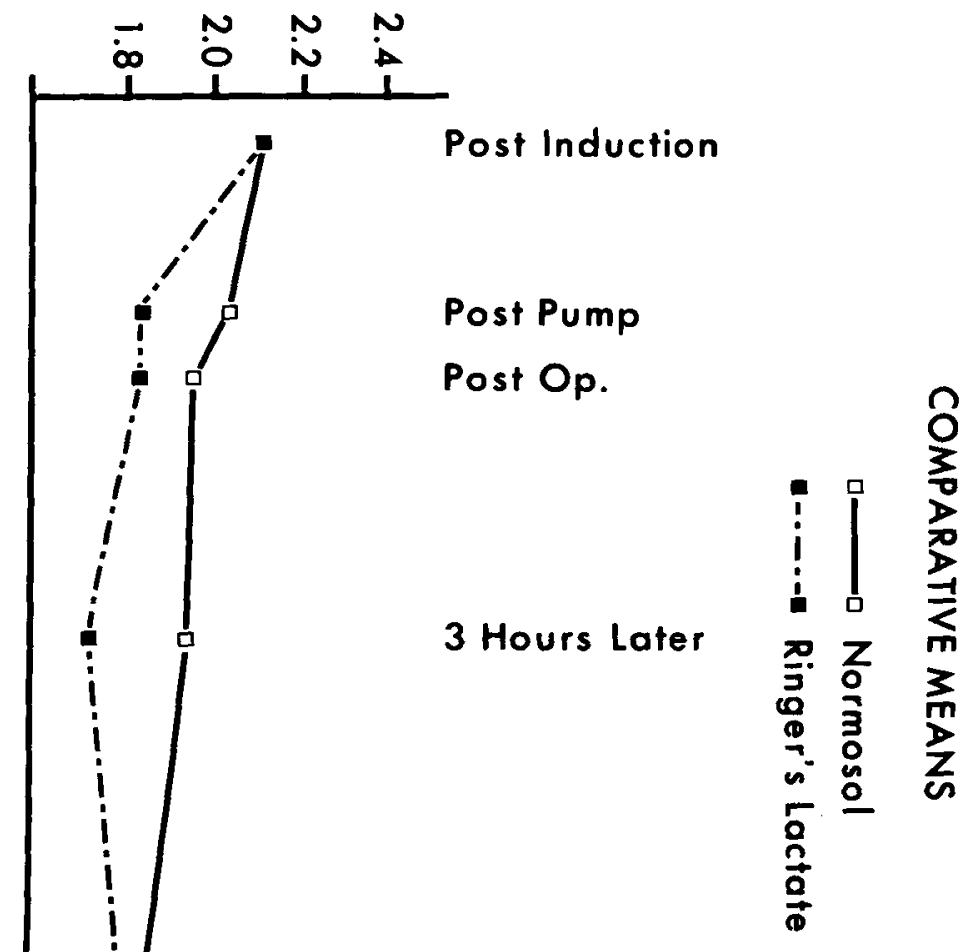

FIGURE 7. Serum magnesium (comparative means with Ringer's lactate and normosomal).

reduce the intra-operative decrease of serum magnesium. The haemodilution pump primes for six patients included 1,500 milliliters of Normosol $\mathbf{R}^{*}$ which contained $3 \mathrm{mEq}$ magnesium per liter of solution or 55 milligrams in 1,500 milliliters. Five patients received a buffered lactated Ringer's blood prime in which the only magnesium present was that in the transfused blood.

The patients in each series had comparable cardiac lesions (Table IV). The mean blood loss and pump times were comparable. The selection of a disc versus a bubble oxygenator did not appear to influence the change in serum magnesium concentrations.

Serum specimens were drawn after induction of anaesthesia, at the end of cardiopulmonary bypass, at the end of surgery, three hours post-operatively and the first post-operative morning. The mean values for lactated Ringer's and Normosol haemodilution prime groups are plotted in Figure 7. The

-Abbott Laboratories Limited, 5400 Cote de Liesse Road, Montreal 101, P.Q. 
TABLE V

Magnesium Excretion During and After Cardiac Surgery

\begin{tabular}{lcc} 
& \multicolumn{2}{c}{ Pump Prime } \\
\cline { 2 - 3 } & Normosol - Blood & Ringer's Blood \\
\hline (A) Average Magnesium Excretion & & \\
1. Intra-operative & $29.2 \mathrm{mg}$ & $29.7 \mathrm{mg}$ \\
2. 0-18 hours post-operative & $98.3 \mathrm{mg}$ & $47.7 \mathrm{mg}$ \\
3. 18-42 hours post-operative & $64.7 \mathrm{mg}$ & $30.4 \mathrm{mg}$ \\
(B) Average Urine Volume & & \\
1. Intra-operative & $231 \mathrm{ml}$ & $265 \mathrm{ml}$ \\
2. 0-18 hours post-operative & $690 \mathrm{ml}$ & $555 \mathrm{ml}$ \\
3. 18-42 hours post-operative & $784 \mathrm{ml}$ & $848 \mathrm{ml}$ \\
\hline
\end{tabular}

mean change between the induction and post-pump values for the Normosol group was $-0.1 \mathrm{mg} \%$ with a range of zero change to $-0.2 \mathrm{mg} \%$. The lactated Ringer's group showed a greater decrease. The mean decrease in the lactated Ringer's group was $-0.3 \mathrm{mg} \%$ with a range of -0.1 to $-0.5 \mathrm{mg} \%$. Since the standard deviation of the means of both groups in the post-pump determinations is $\pm-2 \mathrm{mg} \%$, there is a marginally significant difference $(P=5 \%)$ between the two groups.

The mean value of the lactated Ringer's primed patients remained lower until the following morning.

The two previously published reports demonstrated a greater intra-operative loss of magnesium than we have recorded.46,47 This difference can be attributed to the different techniques of fluid and blood replacement. The earlier investigators employed an electrolyte prime, while in our series one to four units of blood have been added to the priming solutions and an additional one to three units of blood given intra-operatively. The concentration of magnesium in the plasma of stored blood parallels the serum concentration. Magnesium losses through blood loss are replaced by blood transfusion.

It is difficult to interpret the clinical significance of the acute fall in serum magnesium which may occur during cardiopulmonary bypass when magnesium is not included in the pump priming solution. The success which other authors have demonstrated in using magnesium to aid in defibrillating patients with persistent ventricular fibrillation and in correcting digitalisinduced dysrhythmias in the hypomagnesaemic patients suggests that the acute loss of magnesium may be important clinically. $48,49,50$

In the interests of conserving blood, some patients at the Vancouver General Hospital are now receiving an electrolyte perfusate during cardiopulmonary bypass without added blood. The electrolyte solutions employed contain $3 \mathrm{mEq}$ of magnesium per liter of solution. We believe that it is important to maintain normal serum magnesium concentrations during and after cardiopulmonary bypass.

(B) Magnesium Excretion During Cardiopulmonary Bypass

Since cardiopulmonary bypass may cause a significant diuresis in some 
patients, we measured the excretion of magnesium. Intra-operative and postoperative urine volumes and magnesium excretion are recorded in Table V.

The excretion of magnesium was measured in all patients during surgery. Despite minor individual variations, the average excretion of magnesium intra-operatively was nearly identical for both the Normosol and Ringer's groups. Urinary excretion did not account for the difference in mean postpump serum values.

We continued post-operative collections of urine from three patients from each group who did not receive diuretics post-operatively. While there is an insufficient number of patients to permit statistical confirmation, there is a striking difference in the quantity of magnesium excreted. Those patients who did not receive supplemental magnesium as part of the pump prime show a marked degree of conservation of magnesium. In each time period they excreted less than half the amount passed by those patients who received Normosol. We interpret these results to indicate that the patients who developed an acute magnesium deficiency during surgery were obliged to respond with an accelerated degree of tubular reabsorption of magnesium. The magnesium deficit appears to be significant in homeostasis.

The patients who received supplemental magnesium in the electrolyte prime did not have to employ such a marked degree of renal conservation of magnesium.

\section{SUMMARY}

We have presented the results of serial serum magnesium determinations during spinal anaesthesia, general anaesthesia and cardiopulmonary bypass.

We have not observed any significant changes in serum concentrations of magnesium which could be related to the administration of anaesthetic agents. The hormonal controls which maintain normal serum magnesium concentrations within a narrow range appear to be unimpaired by anaesthetic agents.

Our preliminary findings suggest that plasma magnesium concentrations in whole blood stored in Acid-Citrate-Dextrose solution remain remarkably close to the serum concentration of magnesium.

Our results refer to total serum magnesium concentrations only. Other investigators may find significant variations in the ionized fraction of serum magnesium when it becomes possible to measure this important parameter accurately.

Two areas of current clinical significance to anaesthetists are the effect of preexisting derangements of magnesium content and alterations in serum magnesium during cardiopulmonary bypass.

Hypermagnesaemia and hypomagnesaemia may have deleterious effects on surgical patients. While anaesthetic agents do not alter serum magnesium values, an abnormal response to anaesthetic agents, particularly muscle relaxants, may occur in the hypermagnesaemic patient.

Significant falls in serum magnesium concentrations may occur during cardiopulmonary bypass when magnesium free solutions are used as priming fluids. Acute hypomagnesaemia during and after cardiopulmonary bypass may be related to persistent ventricular fibrillation and digitalis-induced dysrhythmias. 
Parenteral magnesium therapy aids in correcting or preventing dysrhythmias in hypomagnesaemic patients. Hypomagnesaemia following cardiopulmonary bypass may be diminished or eliminated by selecting magnesium-containing electrolyte solutions for haemodilution.

\section{RÉSUMÉ}

Nous avons présenté les résultats de séries de déterminations du taux de magnésium sérique durant l'anesthésie rachidienne, l'anesthésie générale et la circulation extra-corporelle.

Nous n’avons pas noté de changements appréciables des taux de magnésium sérique qui pourraient être attribuables à l'administration d'agents anesthésiques. Les contrôles hormonaux qui maintiennent les taux de magnésium sérique en deça d'une marge étroite ne semblent pas être dérangés par les agents anesthésiques.

Nos résultats préléminaires nous laissent croire que les taux de magnésium plasmatique dans le sang total conservé dans la solution d'acide-citrate-dextrose demeurent remarquablement près du taux de magnésium chronique.

Nous faisons allusion seulement aux taux de magnésium sérique total. Actuellement, il n'est pas possible de mesurer avec précision le pourcentage de magnésium sérique ionisé.

Il existe deux éventualités qui, pour les anesthésistes, prennent une importance clinique ce sont: l'effet d'un désiquilibre pré-existant du contenu de magnésium et, ensuite, les modifications du magnésium sérique durant la circulation extracorporelle.

Chez les malades soumis à la chirurgie, l'hyper aussi bien que l'hypomagnésiémie peut produire des effets indésirables. Même si les agents anesthésiques ne modifient pas les valeurs du magnésium sérique, une réponse anormale aux agents anesthésiques, plus particulièrement aux myorésolutifs, peut survenir chez les porteurs d'hypermagnésiémie.

Des diminutions importantes des taux de magnésium sérique peut apparaître au cours de la circulation extra-corporelle, si l’on emploie des solutions sans magnésium pour amorcer la pompe. Une hypomagnésiémie aigue durant et après une circulation extra-corporelle peut ne pas être étrangère aux dysrythmies produites par la digitaline et à la fibrillation ventriculaire persistante. La thérapie parentérile du magnésium peut aider à corriger ou à prévenir les dysrythmies chez les hypomagnésiémiques. L'hypomagnésiémie consécutive à la circulation extra-corporelle peut être éliminée ou diminuée en choisissant comme solutions hémodiluantes des solutions contenant du magnésium.

\section{ACKNOWLEDGMENTS}

We would like to express our deep gratitude to Miss Florence Yakura and Mr. Thomas U of the Chemistry Laboratory, Vancouver General Hospital for many hours of voluntary assistance. We are indebted to Mrs. Patricia Trapp for the statistical analysis. 


\section{REFERENCES}

1. AlCock, N.W. Development of methods for the measurement of magnesium. Ann. N.Y. Acad. Sci. 162. Art. 2: 707 (1969).

2. VACHON, M. \& MARCHAND, C. The influence of morphine on magnesium metabolism in rats. J. Pharm. Exp. Ther, 172: 122 (1970).

3. Berman, M.C., Harkison, G.G., Bull, A.B., \& Kench, J.E. Changes underlying halothane-induced malignant hyperpyrexia in landrace pigs. Nature 225: 653 (1970).

4. Wacker, W.E.C. \& Parusi, A.F. Magnesium metabolism. N. Engl. J. Med. 278: 658$663,712-717,772-776$ (1968).

5. WACKER, W.E.C. The biochemistry of magnesium. Ann. N.Y. Acad. Sci. 162, Art. 2:

6. Ibid. 717 (1969).

7. WeLt, L.G. \& BLythe, W.B. In The Pharmacological Basis of Therapeutics. Fourth Ed., Ed. by Goodman, L.S. \& Gilman, A. New York: Macmillan p. 812 (1970).

8. Wacker, W.E.C. \& PArusi, A.F. New Engl. J. Med. 278: 659 (1968).

9. Estep, H., Shaw, W., Watlington, C.O., Hobe, C., Holland, W., \& Tucker, H. Hypocalcemia due to reversible PTH resistance. Clin. Res. 16: 265 (1968).

10. Evans, R.A., Forbes, M.A., Sutton, R.A.L., \& Watson, L. Urinary excretion of calcium and magnesium in patients with calcium-containing renal stones. Lancet $i i$ : 958 (1967).

11. SeELIG, M.S. Electrographic patterns of magnesium depletion appearing in alcoholic heart disease. Ann. N.Y. Acad. Sci. 162, Art. 2: 906 (1969).

12. Welt, L.G. \& Blythe, W.B. In The Pharmacological Bais of Therapeutics. Fourth Ed. p. $813(1970)$.

13. deL CAstillo, J. \& ENGBaEk, L. Nature of neuromuscular block produced by magnesium. J. Physiol. Long. 124: 370 (1954).

14. Wacker, W.E.C. \& Parisi, A.F. New Engl. J. Med. 278: 712 (1968).

15. Ibid.

16. Henzel, J.H., DeWeese, M.S., \& Rudenhour, G. Significance of magnesium and zinc metabolism in the surgical patient. I. Magnesium. Arch. Surg. 95: 974 (1967).

17. Barnes, B.A. Magnesium conservation: a study of surgical patients. Ann. N.Y. Acad. Sci. 162, Art. 2: 786 (1969).

18. Brovghton, A., Anderson, I.R.M., \& Bowden, C.H. Magnesium deficiency syndrome in burns. Lancet $i i$ : 1156 ( 1968 ).

19. Wacker, W.E.C., MoOre, F.D., Ulmer, D.D., \& ValleE, B.C. Normocalcemic magnesium deficiency tetany. J.A.M.A. 180: 161 (1962).

20. SeELiG, M.S. Ann. N.Y. Acad. Sci. 162, Art. 2: 906 (1969).

21. Heccrveit, H.A. Myopathy in experimental magnesium deficiency. Ann. N.Y. Acad. Sci. 162, Art. 2758 (1969).

22. WACKER, W.E.C. \& PArisI, A.F. New Engl. J. Med. 278: 774 (1968).

23. Flink, E.B. Therapy of magnesium deficiency. Ann. N.Y. Acad. Sci. 162, Art. 2: 901 (1969).

24. Randali, R.E., Cohen, MD., Spray, C.C., Jr., \& Rossmeise, E.C. Hypermagnesemia in renal failure, etiology and toxic manifestations. Ann. Int. Med. $i$ : 73 (1970).

25. Ditzler, J.W. Epsom-salts poisoning and a review of magnesium-ion physiology. Anesthesiology 32: 378 ( 1970).

26. Sikal, M.M., Koenigsberger, M.R., Rose, J.S., Berdon, W.E., \& Santulli, T.V. Neonatal hypermagnesemia and the medonium-plug syndrome. New Engl. J. Med. 286: 823 (1972).

27. Wacker, W.E.C. \& Parisi, A.F. New Engl. J. Med. 278: 713 (1968).

28. Ibid.

29. Op cit., p. 774.

30. BUKY, B. Effect of magnesium on ventricular fibrillation due to hypothermia. Brit. J. Anaesth. 42: 886 (1970).

31. Scheinman, M.M., Sullivan, R.W., \& Hyatt, K.H. Magnesium metabolism in patients undergoing cardiopulmonary bypass. Circulation 39, Suppl. I: 235 (1969).

32. PECK, C.H. \& MALTZER, S.J. Anesthesia in human beings by intravenous injection of magnesium sulphate. J.A.M.A. $67: 113$ (1916).

33. SomJen, G., Humy, M., \& StePhEN, C.R. Failure to anaesthetize human subjects by intravenous administration of magnesium sulfate. J. Pharmacol. \& Exper. Therap. 154: 652 ( 1966 ).

34. Kato, G,, Keily, J.S., Krnjevic, K., \& Somjen, G. Anaesthetic action of magnesium ions. Can. Anaes. Soc. J. 15: 539 (1968). 
35. Aldrete, J.A., Zahler, A., \& Aikawa, J.K. Prevention of succinylcholine-induced hyperkalaemia by magnesium sulfate. Can. Anaes. Soc. J. 17: 477 (1970).

36. WACKer, W.E.C. \& PARISI, A.F. New Engl. J. Med. 278: 773 (1968).

37. Seller, R.H., Romirez-Muxo, O., Brest, A.N., \& Moyer, J.H. Magnesium deficiency in hypertension. J.A.M.A. 191: 653 (1965).

38. Wacker, W.E.C. \& Parisi, A.F. New Engl. J. Med. 278: 773 ( 1968 ).

39. Seller, R.H. The role of magnesium in digitalis toxicity. Amer. Heart J. 82: 55I (1971).

40. SzEKELY, P. \& WYNNE, N.A. Effects of magnesium on cardiac arrhythmias caused by digitalis. Clin. Sc, 10:241 (1951).

41. Ghoneim, M.M. \& Long, J.P. The interaction between magnesium and other neuromuscular blocking agents. Anesthesiology 32: 23 (1970).

42. Vachon, M. \& Marchand, C. J. Pharmacol. Exp. Ther. 172: 122 (1970).

43. Berman, M.C., Harrison, G.G., Buld, A.G., \& Kench, J.E. Changes underlying halothane-induced malignant hyperpyrexia in landrace pigs. Nature 225: 653 (1970).

44. Dieter, R.A., Neville, W.E., \& Pifarre, R. Serum electrolyte changes after cardiopulmonary bypass with Ringer's lactate solution used for hemodilution. J. Thorac. Cardiovasc. Surg. 59: 168 (1970).

45. Scheinman, M.M., Sullivan, R.W., \& Hyatt, K.H. Magnesium metabolism in patients

46. Ibid. undergoing cardiopulmonary bypass. Circulation 39: Suppl. I: 235 (1969).

47. Dieter, R.A., Neville, W.E., \& Pifarre, R. Serum electrolyte changes after cardiopulmonary bypass with Ringer's lactate solution used for hemodilution. J. Thorac. Cardiovasc. Surg. 59: $168(1970)$.

48. Seller, R.H. The role of magnesium in digitalis toxicity. Amer. Heart. J. $82: 551$ (1971).

49. BukY, B. Effect of magnesium on ventricular fibrillation due to hypothermia. Brit. J. Anaesth. 42: 886 (1970).

50. Scheinman, M.M., Sullivan, R.W., \& Hyatt, K.H. Magnesium metabolism in patients undergoing cardiopulmonary bypass. Circulation 39, Suppl. 1: 235 (1969). 